The New Science 
This page intentionally left blank 


\title{
The New Science
}

\author{
Giambattista Vico
}

Translated and Edited by Jason Taylor and Robert Miner with an Introduction by Giuseppe Mazzotta

Yale UNIVERSITY PRESS

New Haven and London 
Published with assistance from the Annie Burr Lewis Fund.

Copyright (C) 2020 by Yale University.

All rights reserved.

This book may not be reproduced, in whole or in part, including illustrations, in any form (beyond that copying permitted by Sections 107 and 108 of the U.S. Copyright Law and except by reviewers for the public press), without written permission from the publishers.

Yale University Press books may be purchased in quantity for educational, business, or promotional use. For information, please e-mail sales.press@, yale.edu (U.S. office) or sales@yaleup.co.uk (U.K. office).

Designed by Angie Sheltz, Newgen.

Set in Times New Roman MT type by Newgen North America.

Printed in the United States of America.

Library of Congress Control Number: 2019940873

ISBN 978-0-300-19113-4 (paperback : alk. paper)

A catalogue record for this book is available from the British Library.

This paper meets the requirements of ANSI/NISO Z39.48-1992 (Permanence of Paper).

109876554321 